\title{
The British Traditional Ballad in North America
}


THIS PAGE INTENTIONALLY LEFT BLANK 
BIBLIOGRAPHICAL AND SPECIAL SERIES PUBLISHED THROUGH THE COOPERATION OF THE AMERICAN FOLKLORE SOCIETY 
THIS PAGE INTENTIONALLY LEFT BLANK 


\title{
The British Traditional Ballad in North America
}

\author{
REVISED EDITION
}

by Tristram Potter Coffin

With a Supplement by Roger deV. Renwick 
Library of Congress Cataloging in Publication Data

Coffin, Tristram Potter, 1922-

The British traditional ballad in North America.

(Publications of the American Folklore Society, bibliographical and special series)

Bibliography: $p$.

Discography: p.

Includes index.

1. Ballads, English-United States-History

and criticism. 2. Ballads, American-History

and criticism. I. Renwick, Roger deV., 1941-

II. Title. III. Series: American Folklore

Society. Bibliographical and special series.

ML3553.C6 $1977 \quad 784.4^{\prime} 973 \quad 76-52476$

ISBN 0-292-70719-3

Copyright 1950, 1963 by American Folklore Society; Copyright (C) 1977 by University of Texas Press

All rights reserved

Printed in the United States of America 
To the memory

of my father:

Tristram Roberts Coffin 
THIS PAGE INTENTIONALLY LEFT BLANK 